\title{
Ability of 'Valencia' Sweet Orange to Cold-acclimate on Cold-sensitive Citron Rootstock
}

\author{
G. Yelenosky and J.C.V. Vu \\ U.S. Department of Agriculture, Agricultural Research Service, \\ Horticultural Research Laboratory, 2120 Camden Road, Orlando, \\ FL 32803
}

Additional index words. Citrus, Poncirus, acclimation, freeze survival, carbohydrates, proline, supercooling

\begin{abstract}
Greenhouse-grown l-year-old sweet orange trees [Citrus sinensis (L.) Osbeck cv. Valencia] on cold-hardy trifoliate orange [Poncirus trifoliata (L.) Raf.] and cold-sensitive citron $(C$. medica $\mathbf{L}$.) rootstocks were exposed to cold-acclimation conditions and freeze-tested at $\mathbf{- 6 . 7 C}$ for 4 hours in a temperature-programed walk-in freezer room. Nonhardened trees generally did not survive the freeze, whereas coldhardened trees survived with no wood kill on either rootstock. Essentially, all leaves died or abscised during the subsequent 5 weeks in the greenhouse. Freeze survival did not separate rootstocks nor did supercooling in separate trials where Yalencia' wood reached $-8.8 \mathrm{C}$ before apparent nucleation. Increases in concentration of carbohydrates and proline and decreases in water content in Yalencia' leaves during cold hardening were generally associated with increased freeze tolerance. Other tests, that matched 9-month-old seedlings of citron with trifoliate orange rootstock, showed clear differences in the superior cold acclimation of trifoliate orange over citron, which, however, performed better than expected.
\end{abstract}

The ability of citrus trees to survive freezes is often associated with the cold hardiness trait of the rootstock (Hearn et al., 1963; Paton et al., 1982; Yelenosky, 1985). Presumably, the less cold hardy the rootstock (tested as seedling trees), the more freeze damage to the scion. There are exceptions (Yelenosky and Hearn, 1967), and differences in freeze damage may not clearly express differences in cold hardiness of the rootstock in citrus field plantings (Gardner and Horanic, 1963; Rouse et al., 1990; Wheaton et al., 1986). Such observations suggest that much more study is needed to assess cause and effect in frozen citrus orchards. Most of the freeze injury observations on citrus scions/rootstocks have been incorporated into data bases that provide useful information to the industry and citrus repositories for comprehensive assessment of germplasm performance and genetic attributes. Such assessments are invaluable in addressing consumer demands, managing quality of existing inventories, developing economic strategies, and providing guidelines for plant genome initiatives.

The objective of this study was to determine whether cold acclimation of young trees

Received for publication 14 Feb. 1992. Accepted for publication 1 July 1992. Mention of a trademark, warranty, proprietary product, or vendor does not constitute a guarantee by the U.S. Department of Agriculture and does not imply its approval to the exclusion of other products or vendors that may also be suitable. The cost of publishing this paper was defrayed in part by the payment of page charges. Under postal regulations, this paper therefore must be hereby marked advertisement solely to indicate this fact. micronutrient elements added (Premier Brands, New Rochelle, N.Y.)]. Similarly, seedlings of citron and trifoliate orange were grown for rootstock seedling freeze trials. Single-stem trees/seedlings were maintained in a 50\% shaded greenhouse under naturalday conditions. The greenhouse air ranged from $33 \mathrm{C}$ during the day to $16 \mathrm{C}$ at night. Maximum photosynthetic photon flux (PPF) was $1000 \mu \mathrm{mol} \cdot \mathrm{m}^{-2} \cdot \mathrm{s}^{-1}$ at the top of the trees, and relative humidity ranged from a low of $34 \%$ during the day to $99 \%$ at night. Trees were watered every 2 days and fertilized monthly with a solution of $12 \mathrm{~N}-2.6 \mathrm{P}-5 \mathrm{~K}$ that contained micronutrients. Plants tested were 96 to $130 \mathrm{~cm}$ tall with 0.8 . to $2.1-\mathrm{cm}$ trunk diameters, $10 \mathrm{~cm}$ above the bud union for grafted trees, and 52 to $88 \mathrm{~cm}$ tall with 0.5 to $0.8-\mathrm{cm}$ midstem diameters for rootstock seedlings. A total of 160 seedlings and 80 budded trees for each rootstock was freezetested.

Test trials included uniform-appearing, greenhouse-grown plants that were cold acclimated in controlled-environment rooms described by Yelenosky (1979) and nonacclimated controls left in the greenhouse. Programed tempertures, relative humidity, and light conditions during cold acclimation are footnoted in Tables 1 and 2. Concentrations of carbohydrates, amino acids, water status, and osmotic potential of expressed sap in leaves were determined in duplicates from prefreeze composite leaf samples of three leaves per plant using methods and procedures described by Yelenosky and Guy (1977, 1982). Respective freeze tests were done in a separate room, adjacent to cold-hardening rooms, using standard operational procedures and lethal freeze limits (Yelenosky, $1976,1991)$. There were no attempts to nucleate the trees with cold water or any other agent during critical freeze tests. Variability in supercooling was determined in separate tests on 12 grafted trees replicated on three consecutive days. Also, bud unions $\approx 7 \mathrm{~cm}$ above soil level were unprotected.

Results of freeze tests in tree damage clearly separated cold-hardened from nonhardened trees on both rootstocks (Table 1). However,

Table 1. Concentration of various leaf components of ten 1-year-old 'Valencia' scions on either trifoliate orange or 'Etrog' citron rootstocks before and after cold-hardening treatments, plus subsequent freeze damage.

\begin{tabular}{|c|c|c|c|c|}
\hline \multirow[b]{2}{*}{ Variable } & \multicolumn{2}{|c|}{ Trifoliate orange } & \multicolumn{2}{|c|}{ Etrog citron } \\
\hline & Nonhardened $^{z}$ & Cold hardenedy & Nonhardened & Cold hardened \\
\hline Component & \multicolumn{4}{|c|}{$m g / g d r y w t$} \\
\hline Sucrose & $34 \pm 2^{x}$ & $48 \pm 1$ & $28 \pm 2$ & $36 \pm 2$ \\
\hline Total sugar & $47 \pm 2$ & $76 \pm 2$ & $40 \pm 2$ & $56 \pm 2$ \\
\hline Starch & $13 \pm 2$ & $94 \pm 1$ & $12 \pm 1$ & $31 \pm 1$ \\
\hline Proline & $13 \pm 1$ & $21 \pm 1$ & $11 \pm 1$ & $17 \pm 1$ \\
\hline Total amino acids & $20 \pm 2$ & $22 \pm 1$ & $34 \pm 2$ & $18 \pm 1$ \\
\hline Water (g/g dry wt) & $2.1 \pm 0.1$ & $1.6 \pm 0.1$ & $2.3 \pm 0.2$ & $1.9 \pm 0.1$ \\
\hline Osmotic potential $(\mathrm{mOsm} / \mathrm{kg})$ & $715 \pm 2$ & $902 \pm 1$ & $622 \pm 1$ & $734 \pm 1$ \\
\hline \multicolumn{5}{|l|}{ Freeze $(-6.7 \mathrm{C}, 4 \mathrm{~h})$} \\
\hline Leaves killed (\%) & 100 & $95 \pm 2$ & 100 & $99 \pm 1$ \\
\hline Stems killed (\%) & $94 \pm 6$ & 0 & 100 & 0 \\
\hline
\end{tabular}

${ }^{\mathrm{z}}$ Greenhouse under natural daylight.

${ }^{\mathrm{y}} 21 \mathrm{C}, 12$-h day $\left(\approx 460 \mu \mathrm{mol} \cdot \mathrm{m}^{-2} \cdot \mathrm{s}^{-1}\right.$ photosynthetic photon flux $), 10 \mathrm{C}$ night, and $50 \% \pm 5 \%$ relative humidity for 2 weeks immediately followed by 2 weeks of $15 / 4 \mathrm{C}$.

${ }^{\mathrm{x}}$ Mean $\pm \operatorname{SD}(\mathrm{n}=3)$. 
Table 2. Concentration of various components in 9-month-old cold-hardy trifoliate orange and cold-sensitive citron seedlings and percentage of 10 seedlings killed at each of four freezing conditions.

\begin{tabular}{|c|c|c|c|c|c|c|c|c|c|c|c|c|}
\hline \multirow{3}{*}{$\begin{array}{l}\text { Temp } \\
\text { (day/night) }\end{array}$} & \multirow{3}{*}{$\begin{array}{l}\text { Days } \\
\text { (no.) }\end{array}$} & \multirow[b]{3}{*}{ Seedling } & \multirow[b]{3}{*}{ Tissue } & \multicolumn{5}{|c|}{ Total } & \multicolumn{4}{|c|}{ Freeze kill ${ }^{2}(\%)$} \\
\hline & & & & Sucrose & Sugars & Starch & Proline & \multirow{2}{*}{$\begin{array}{c}\text { Water } \\
\text { (g/g dry wt) }\end{array}$} & \multicolumn{4}{|c|}{$\operatorname{Temp}\left({ }^{\circ} \mathrm{C}\right)$} \\
\hline & & & & \multicolumn{4}{|c|}{ (mg/g dry wt) } & & $-5(4 h)$ & $-6.7(4 h)$ & $-8.9(4 h)$ & $-14(0.25 \mathrm{~h})$ \\
\hline \multirow[t]{4}{*}{ Greenhouse } & \multirow[t]{4}{*}{0} & \multirow[t]{2}{*}{ Trif. orange } & Leaves & $34 \pm 1^{y}$ & $38 \pm 1$ & $36 \pm 1$ & $9 \pm 1$ & $1.9 \pm 0.1$ & $52 \pm 14$ & 100 & 100 & 100 \\
\hline & & & Stem & $20 \pm 1$ & $23 \pm 1$ & $4 \pm 1$ & $8 \pm 1$ & $1.6+0.1$ & $2 \pm 1$ & $79 \pm 8$ & 100 & $83 \pm 17$ \\
\hline & & \multirow[t]{2}{*}{ Citron } & Leaves & $45 \pm 1$ & $57 \pm 1$ & $16 \pm 1$ & $5 \pm 1$ & $3.0 \pm 0.1$ & $81 \pm 18$ & 100 & 100 & 100 \\
\hline & & & Stem & $48 \pm 1$ & $62 \pm 1$ & $18 \pm 1$ & $4 \pm 1$ & $2.8 \pm 0.5$ & $75 \pm 25$ & 100 & 100 & 100 \\
\hline \multirow[t]{4}{*}{$21 / 10 C^{x}$} & \multirow[t]{4}{*}{14} & \multirow[t]{2}{*}{ Trif. orange } & Leaves & $64 \pm 1$ & $74 \pm 1$ & $45 \pm 1$ & $15 \pm 1$ & $1.5 \pm 0.2$ & 0 & $41 \pm 18$ & 100 & 100 \\
\hline & & & Stem & $50 \pm 1$ & $62 \pm 1$ & $22 \pm 1$ & $11 \pm 1$ & $1.2 \pm 0.1$ & 0 & 0 & $10 \pm 1$ & $67 \pm 20$ \\
\hline & & \multirow[t]{2}{*}{ Citron } & Leaves & $64 \pm 1$ & $85 \pm 1$ & $27 \pm 2$ & $8 \pm 1$ & $2.6 \pm 0.2$ & $60 \pm 25$ & 100 & 100 & 100 \\
\hline & & & Stem & $55 \pm 1$ & $77 \pm 1$ & $44 \pm 1$ & $9 \pm 1$ & $2.1 \pm 0.2$ & $39 \pm 23$ & $86 \pm 11$ & 100 & 100 \\
\hline \multirow{4}{*}{$15 / 4 C^{w}$} & \multirow[t]{4}{*}{14} & \multirow[t]{2}{*}{ Trif. orange } & Leaves & $94 \pm 2$ & $114 \pm 2$ & $19 \pm 1$ & $22 \pm 1$ & $1.5 \pm 0.1$ & 0 & 0 & 0 & $\cdots$ \\
\hline & & & Stem & $58 \pm 1$ & $72 \pm 1$ & $7 \pm 1$ & $15 \pm 1$ & $1.1 \pm 0.1$ & 0 & 0 & 0 & $16 \pm 10$ \\
\hline & & \multirow[t]{2}{*}{ Citron } & Leaves & $65 \pm 1$ & $83 \pm 1$ & $31 \pm 1$ & $9 \pm 1$ & $2.3 \pm 0.7$ & $28 \pm 12$ & $60 \pm 24$ & 100 & 100 \\
\hline & & & Stem & $68 \pm 1$ & $83 \pm 1$ & $33 \pm 1$ & $8 \pm 1$ & $1.9 \pm 0.1$ & $20 \Perp 14$ & $54 \pm 22$ & 100 & 100 \\
\hline \multirow[t]{4}{*}{$15 / 4 \mathrm{C}$} & \multirow[t]{4}{*}{28} & \multirow[t]{2}{*}{ Trif. orange } & Leaves & $76 \pm 2$ & $98 \pm 2$ & $5 \pm 1$ & -- & $1.5 \pm 0.2$ & 0 & 0 & 0 & --- \\
\hline & & & Stem & $65 \pm 1$ & $77 \pm 1$ & $11 \pm 1$ & -- & $0.9 \pm 0.1$ & 0 & 0 & 0 & 0 \\
\hline & & \multirow[t]{2}{*}{ Citron } & Leaves & $62 \pm 1$ & $74 \pm 1$ & $32 \pm 1$ & $\cdots$ & $2.2 \pm 0.3$ & $40 \pm 20$ & 100 & 100 & $\cdots$ \\
\hline & & & Stem & $58 \pm 1$ & $72 \pm 1$ & $59 \pm 1$ & -- & $2.1 \pm 0.3$ & $38 \pm 16$ & 100 & 100 & $\cdots$ \\
\hline
\end{tabular}

${ }^{\mathrm{z}}$ Temperature decreased $1.1 \mathrm{C} / \mathrm{h}$, after $2 \mathrm{~h}$ equilibration at $4 \mathrm{C}$, to respective minima and durations without light; thaw rates $1.1 \mathrm{C} / \mathrm{h}$ to $4 \mathrm{C}$.

${ }^{\mathrm{y}}$ Means $\pm \mathrm{SD}(\mathrm{n}=3)$ for tissue analyses, and means \pm SE $(\mathrm{n}=10)$ for freeze kill.

${ }^{\mathrm{x}} 21 \mathrm{C}, 12-\mathrm{h}$ day $\left(460 \mu \mathrm{mol} \cdot \mathrm{m}^{-2} \cdot \mathrm{s}^{-1}\right.$ photosynthetic photon flux $), 10 \mathrm{C}$ night and $50 \% \pm 5 \%$ relative humidity.

${ }^{\mathrm{w}} 15 \mathrm{C} 12-\mathrm{h}$ day $\left(460 \mu \mathrm{mol} \cdot \mathrm{m}^{-2} \cdot \mathrm{s}^{-1}\right.$ photosynthetic photon flux $), 4 \mathrm{C}$ night and $50 \% \pm 5 \%$ relative humidity.

differences in scion freeze damage of coldacclimated trees did not separate cold-hardy trifoliate orange from cold-sensitive citron rootstock. 'Valencia' scion essentially was killed without cold acclimation but survived with no apparent wood damage after cold acclimation on either trifoliate orange or 'Etrog' citron. Apparent increases in solute concentrations and decreased water content that were found in leaves of cold-hardened trees compare favorably with known coldacclimation events in citrus (Yelenosky and Guy, 1982). The differences found in solute concentrations and water content between rootstocks are difficult to interpret because of no significant differences in freeze survival of trees after cold acclimation. Higher solute concentrations and lower water content in leaves of cold-acclimated 'Valencia' on trifoliate orange rootstock suggest a greater freeze tolerance than trees on citron rootstock that survived equally as well. In this instance, a temperature lower than $-6.7 \mathrm{C}$ might have been needed to separate rootstocks that were not expected to have equal scion survival after cold acclimation and subsequent freeze test. Leaf tissue analyses apparently are not totally adequate to express rootstock influence on scion freeze tolerance, especially with young trees, which do not acclimate to the same level as mature trees; thus, the results of this study may not apply to mature trees (Young et al., 1960). Very little is known about rootstock influence in citrus cold hardening other than an apparent significant association with degree of damage in freeze situations (Rouse et al., 1990; Yelenosky et al., 1981), and some association with citrus "dormancy" (Young, 1970). We do not know the exact relationship of solute concentration and water content with freeze survival, although there are significant correlations in field studies (Yelenosky and Guy, 1982). How much of an increase in solute concentration and decrease in water content is needed to survive $-6.7 \mathrm{C}$ for $4 \mathrm{~h}$ is not known. In contrast to no wood kill of cold-hardened 'Valencia' trees on citron rootstock (Table 1), citron seedlings showed considerable damage after a similar cold-hardening treatment and subsequent freeze test (Table 2). Our data clearly indicated that citron seedlings are more vulnerable to freeze damage than are trifoliate orange seedlings. Citron's apparent intolerance to freezing temperatures as a seedling was not expressed in budded trees such as 'Valencia' orange on 'Etrog' citron rootstock in this study. The general pattern of increased solutes and decreased hydration during cold acclimation was as evident in seedlings as in budded trees. However, it is not known whether the magnitude of such changes could account for the differences in freeze damage.

There was no indication in this study that supercooling was a significant factor. All trees started to freeze, regardless of rootstock and cold acclimation, from -6.3 to $-7.3 \mathrm{C}$ mean temperatures $\pm 0.4 \mathrm{C}$ SE. The range of supercooling for individual trees was from -4.8 to $-8.8 \mathrm{C}$, not uncommon for young citrus trees under controlled temperatures (Yelenosky, 1991). However, nothing is known about supercooling of mature citrus trees under natural conditions.

The ability of 'Valencia' scion to survive $-6.7 \mathrm{C}$ for $4 \mathrm{~h}$ equally well on rootstocks that represent extremes in citrus cold hardiness demonstrates that the effect of rootstock on scion cold hardiness is not as straightforward as is often assumed. There are instances where rootstocks were separated statistically based on damage when young trees were exposed to a freeze (Yelenosky, 1976), and this raises the level of unknowns in dealing with rootstock influence in citrus freeze survival. For example, the survival of the bud union on the assumed extremely coldsensitive-rated citron rootstock at $-6.7 \mathrm{C}$ for $4 \mathrm{~h}$ was unexpected but was borne out in the seedling trials, which indicated that citron has considerable cold-acclimation potential (Table 2).

Cold hardiness ratings of rootstocks (tested as seedlings) may not necessarily be definitive markers for tree cold hardiness (Young, 1969), and a wide range of cold hardiness ratings of rootstocks may be applicable to management goals (Wheaton et al., 1990). Cold-hardening conditions used in this study may have been near optimal and, therefore, obscured differences in survival that might result during less cold hardening on such a wide range of rootstock cold hardiness. Seemingly, rootstock differences in cold hardiness are best expressed in scions during less-than-optimal cold hardening, and differences would become less noticeable with increases in cold-hardening conditions just before major freezes.

\section{Literature Cited}

Gardner, F.E. and G. Horanic. 1963. Cold tolerance and vigor of young citrus trees on various rootstocks. Proc. Fla. Hort. Soc. 76:105110

Hearn, C.J., W.C. Cooper, R.O. Register, and R. Young. 1963. Influence of variety and rootstock upon freeze injury to citrus trees in the 1962 freeze. Proc. Fla. State Hort. Soc. 76:7581.

Paton, D.M., G.I. Moss, and A.S. Carter. 1982. Frost damage in citrus. Austral. Citrus News July, p. 2.

Rouse, R.E., E.D. Holcomb, Jr., D.P.H. Tucker, and C.O. Youtsey. 1990. Freeze damage sustained by 27 citrus cultivars on 21 rootstocks in the budwood foundation grove, Immokalee. Proc. Fla. State Hort. Soc. 103:64-67.

Wheaton, T.A., W.S. Castle, J.D. Whitney, D.P.H. Tucker. and R.P. Muraro. 1990. A high density citrus Planting. Proc. Fla. State Hort. Soc. 103:55-59.

Wheaton, T.A., J.D. Whitney, W.S. Castle, and D.P.H. Tucker. 1986. Tree spacing and rootstock affect growth, yield, fruit quality, and freeze damage of young 'Hamlin' and 'Valen- 
cia' orange trees. Proc. Fla. State Hort. Soc. 99:29-32.

Yelenosky, G. 1976. Cold hardening young 'Valencia' trees on Swingle citrumelo (C.P.B. 4475) and other rootstocks. Proc. Fla. State Hort. Soc. 89:9-10.

Yelenosky, G. 1979. Accumulation of free proline in citrus leaves during cold hardening of young trees in controlled temperature regimes. Plant Physiol. 64:425-427.

Yelenosky, G. 1985. Cold hardiness in citrus. Hort. Rev. 7:201-237.

Yelenosky, G. 1991. Supercooling and freezing in the main stem of 'Valencia' orange trees. Cryobiology 28:382-390.

Yelenosky, G. and C.J. Hearn. 1967. Cold damage to young mandarin hybrid trees and different rootstocks on flatwood soil. Proc. Fla. State Hort. Soc. 80:53-56.

Yelenosky, G. and C.L. Guy. 1977. Carbohydrate accumulation in citrus. Bot. Gaz. 138:13-17.

Yelenosky, G. and C.L. Guy. 1982. Seasonal variations in physiological factors implicated in cold hardiness of citrus trees, p. 561-573. In: P.H. $\mathrm{Li}$ and A. Sakai (eds.). Plant cold hardiness and freezing stress: Mechanisms and crop implications. vol. 2. Academic, New York.
Yelenosky, G., R. Young, C.J. Hearn, H.C. Barrett, and D.J. Hutchison. 1981. Cold hardiness of citrus trees during the 1981 freeze in Florida. Proc. Fla. State Hort. Soc. 94:46-51.

Young, R. 1970. Induction of dormancy and cold hardiness in citrus. HortScience 5:411-413.

Young, R.H. 1969. Cold hardening in citrus seedlings as related to artificial hardening conditions. J. Amer. Soc. Hort. Sci. 94:612-614.

Young, R.H., A. Peynado, and W.C. Cooper. 1960. Effect of rootstock-scion combination and dormancy on cold hardiness of citrus. J. Rio Grande Valley Hort. Soc. 14:58-65. 